\title{
Farmers' Participation in Rice Straw-Utilisation in the MADA Region of Kedah, Malaysia
}

Rosmiza MZ

School of Social, Development and Environmental Studies, Universiti Kebangsaan Malaysia; Royal Agricultural University, United Kingdom

Email:miza@ukm.edu.my

Davies, WP

School of Agricultural, Food and Environment, Royal Agricultural University, United Kingdom

Rosniza Aznie CR

School of Social, Development and Environmental Studies, Universiti Kebangsaan Malaysia

Mazdi M

Department of Geography and Environment, Universiti Pendidikan Sultan Idris

Jabil MJ

Ethnography and Development Research Unit, Universiti Malaysia Sabah

Wan Toren WY

Brunel Business School, Brunel University London, United Kingdom

Che Rosmawati CM

Brunel Business School, Brunel University London, United Kingdom

Doi:10.5901/mjss.2014.v5n23p229

Abstract

The greater engagement of cereal farmers in better straw-utilisation could probably reduce the adverse impacts of open burning of straw on the environment. However, it seems difficult to achieve with the current knowledge and ability of farmers being limited and also by other external factors. This study attempts, to assess the influence of various environmental and socio-economic factors that influence farmers managing straw in a more environmentally-friendly manner. The study focused on Muda Agricultural Development Authority (MADA) agricultural region in Kedah. It involved 160 farmers, either involved in straw collection by MADA or utilising straw as a by-products for another purpose. Results show that several factors are influencing the stagnation of better straw-utilisation in the MADA region. It includes weather (humidity and rain); incentives that are not commensurate to farmers; inefficient straw collection technology; lack of logistic facilities (baler machines, storage and transportation); low level of skills and knowledge of farmers; inefficient management from agricultural agencies; and lack of capital to manage straw in their fields. Given the economic value and high potential, straw could become much more important by-product for farmers and local communities. Moreover, straw could also stimulate the wider rural economy through addedvalue industrial chain as well as more generally impoving the agricultural environment.

Keywords: environmentally-friendly, farmer, open burning, rice straw, socio-economic, straw-utilisation

\section{Introduction}

Straw yields vary widely between countries and regions in the world (Ministry of Economic Affairs, 2013). It can be influenced by weather conditions, varieties, potential grain yields and farming methods during planting, harvesting and 
straw collecting (Hrynchuk, 1998; Ministry of Economic Affairs, 2013). The on-farm influences involve proper crop management (e.g. reduced lodging of the crop); trafficking patterns during grain harvest (reducing the flattening of straw to the field surface); adjusting grain harvest method (selecting cutting height of the crop); and choosing crop varieties with a certain straw to grain ratio (Ministry of Economic Affairs, 2013).

The ratio of grain harvested to straw used is differs between regions. Typical values for rice straw to grain ratios can vary from 0.7 to 1.5 , which means that for every ton of rice grain, about 700 to $1500 \mathrm{~kg}$ of rice straw is produced (Ministry of Economic Affairs, 2013). In California, the ratio of rice straw to grain is 0.5:0.3 which is based on collection operations in straw bales (Summer et al., 2003). The grain to straw ratio of 0.45:0.55 has been used in Malaysia (MADA, 2014). However, with the latest rice varieties of moderate height, the ratio is almost the same (0.45:0.55), Muda Agricultural Development Authority (MADA) often used the 1:1 ratio to calculate the estimating available straw in MADA region (MADA, 2012).

\section{Literature Review}

Routinely, farmers burn their straw in-situ as a method to clear fields prior to initiating mechanized land preparation (Bird et al., 2002; Einstein, 2011). It is also the most expedient, being the easiest and cheapest way to dispose of straw and can save more time for field management for the next crop due to limited preparation period (Dobermann \& Fairhurst, 2000; Kadam, 2000; Rosmiza et al., 2012). Straw burning is also traditionally done to eliminate sources of pests, diseases and rat infestation including Sclerotium oryzae the fungal pathogen causing stem rot (Kadam, 2000; MADA, 2012; Rosmiza et al., 2012; Kanokkanjana \& Garivait, 2013). However, open-field burning is the most polluting agronomic practice for straw disposal with the emitted smoke. It pollutes air with a various gases especially carbon dioxide $\left(\mathrm{CO}_{2}\right)$, methane $\left(\mathrm{CH}_{4}\right)$ and nitrous oxide $\left(\mathrm{N}_{2} \mathrm{O}\right)$; and fine particles that enhance global climate change and harmful public health on human respiratory ailments (Zhang \& Jenkins, 2004; Bijay-Singh et al., 2008; Kanokkanjana \& Garivait, 2013; Mohd Lokman et al., 2013).

Farmers and policy makers are well-aware of the consequences of on-farm burning (Indian Agricultural Research Institute, 2012). A change on a more regular basis from burning on-field to straw removal or incorporation as a method of disposal would depend on farm circumstances; economic circumtances; appropriate machinery and logistics to handle increasing quantity of residues (Bijay-Singh et al., 2008). Farmers personal preferences focus mainly on costs and benefits; risk of soil compaction; information on the retention of organic matter; and other factors such as new market, valuable products and alternative uses closer to home (Allen-Stevens, 2014). Straw collection also depends on the weather, crop rotation, existing soil fertility, land slop and tillage practices (Kim \& Dale, 2004). Straw removal from the field is widespread in India, Bangladesh and Nepal (Dobermann \& Fairhurst, 2000). Transportation would be the major problem because of the large volumes of straw, although it can be baled (round bales of $450 \mathrm{~kg}$ ). The volume is too high and too heavy for small truck without the issue of illegal overloading for small holder farmers (MADA, 2012; Kanokkanjana \& Garivait, 2013).

In recent years, farmers have been compelled to burn crop residues in India due to shortage of human labour; high cost of removing the crop residues by conventional methods; use of combines for harvesting crops; huge amounts of straw requires the high cost and labour for collection and transportation, reduction numbers of livestocks (Indian Agricultural Research Institute, 2012). In Punjab, the challenges of rice straw proposed in industrial and on-farm uses are collection and storage; machinery; technology dissemination; capacity building; research and development (R\&D) capacity and genomic studies (biotechnological method to reduce silica for raw material industries and fuel) (Department of Science, Technology and Environment, 2013). Due to the shortage of farm labour, straw collection, chopping and baling need to be further addressed. Furthermore, huge quantities of straw in the storage need to be taken care from bacteria/ fungal attacks and fire. For encouraging farmers to manage their straw prudently, The State Government of Punjab provides subsidies on machinery and technologies relating to rice straw management that could be more cost effective. Farmers now also adopt more appropriate agricultural practices and have built capacity, through greater awareness and extension education, provided by Agricultural Service Centres (Department of Science, Technology and Environment, 2013).

In Oromiya Regional State in Ethiopia, farmers report three major constraints for not collecting crop residue of a lack of transportation to collect the bulky nature of crop residue; mulching purpose needs; storage; and others such as fields location being too far from homesteads and also small quantities of straw. Around $90 \%$ of crop residues are collected and stored in the open air. About $30 \%$ to $40 \%$ of farmers indicate that some of their crop residues are wasted due to improper storage and inability to collect. Farmers have to face the storage problem such as mould formation due to rain fall and termite attack, rodents, birds, wind and fire (Tesfaye \& Chairatanayuth, 2007). Mould formation would 
cause the reduction in stover quality and rejection for animal feeding. However, the major constraints in using straw for feeding systems are shortage of labour and capital; and lack of awareness and access to improve straw feeding values. For economic and beneficial practice in Ethiopia and elsewhere, farmers need to be well-trained and continuously advised by extension workers. Proper demonstration to farmers should be done on the nutritive value improvement techniques such as physical processing, supplementation and urea utilization. Research should also be directed both on station and at field level to initially justify feasibility (Tesfaye \& Chairatanayuth, 2007).

According to Glithero et al. (2013), the major reasons given by farmers for not baling or selling cereal straw are the short period of operations for the next crop, and perceived benefits of incorporation to soil structure and soil fertility. The other reasons stated by farmers are weather (unable to bale when straw in wet condition); nutrient retention; arson (concern about security of harvested straw); lack of demand from local market; market prices (returns insufficient); labour, complexity of on farm operations (invest in new machinery). However, several factors that influenced farmers towards managing their straw without open-burning by straw removal or incorporation is getting a 'good price' at the farm-gate; guaranteed market for straw; a fixed minimum price for straw bale; long-term soil quality and nutrient retention influences.

Kadam et al. (2000) also emphasized that rice straw collection sometimes required more consideration of machinery due to the weather especially with long and heavy rain. The soil often turns muddy thereby limiting the use of machinery especially in Asian countries, and also in the United States and Europe when rice is harvested in autumn. Farmer attitudes are also the most important for changing straw disposal methods. In the United States, collection systems reportedly need a proper interface with the farmers own operations. Farmers would not tolerate with interference on harvesting operations and have not been economically motivated to change their operations much to facilitate straw harvesting. Thus, straw harvesting must be put off until the end of the rice harvest proper, or limited to those hours in the day when rice harvesting has been suspended. However, more recent regulation provides farmers with greater economic incentive to cooperate with rice straw collection which may help change attitudes (Kadam et al., 2000).

Slow decomposition of straw in temperate soils and the carry-over of weed seeds and fungal pathogens also has been viewed as a disadvantages to shifting open-burning to other practices (Zhang \& Jenkins, 2004). In the United States, the cost for straw removal tend to be higher around $\$ 60$ to $\$ 250$ per hectare and soil incorporation (\$15 to $\$ 200$ per hectare) compared to open burning only for $\$ 7$ to $\$ 12$ per hectare (Zhang \& Jenkins, 2004). Hence, farmers would burn the straw and defer more straw environmentally-friendly management such as straw removal or straw incorporation (Einstein, 2011).

The MADA region is well-known as the largest rice growing areas in Malaysia (MADA, 2014). It produce about 40\% of the country's rice supply (MADA, 2014). Thus, the potential of straw is high compared to other regions of Malaysia. With a high potential to be industrialized, it could stimulate the agricultural sector such as livestock feed and compost; manufacturing industries such as paper making and food packaging; construction sectors such as building materials and erosion control; and renewable energy such as biofuels, electricity and biogas (India Agriculture Research Institute, 2012; Rosmiza et al., 2012; Department of Science, 2013; Park et al., 2014; Qian, 2014). Thus, rice (main produce) and straw (crop residue) should probably be developed more in tandem without the challenge of wasting resources by burning straw. The present study attempts to elucidate factors that can influence the efforts of farmers to manage straw in a more comprehensive and environmentally-friendly ways in the MADA region of Malaysia. The assessment involves weather considerations, agronomic practices, logistic facilities, institutions and farmers perspectives as influences of successful straw management.

\section{Straw Management in the MADA Region}

MADA region contributes around $40 \%$ of the country's rice supply with two season cultivations per year:

\section{a) First season (off-season)}

Paddy cultivation starts around mid-March and ends in mid-August. During this season, the water supply is obtained through irrigation systems derived from Pedu Dam and Muda Dam. In the middle of the season, from April to September, the fields get water from rainfall due to the southwest monsoon that bring heavy rain to the region. The grain is harvested in mid-August to mid-September (Md. Zuki \& Zulkifli, 2010). During this period, straw collection by machinery could get into problems because of wet soil. In addition, the wet straw could be attacked by fungal problems (Kanokkanjana \& Garivait, 2013; Zulkifli, 2013). Therefore, open-burning is mostly done during May to October. Even though gases and aerosols are released from the straw burning, it can sometimes deposited into the soil subsequently in rain (Kanokkanjana \& Garivait, 2013). 


\section{b) Second season (main season)}

As soon as harvesting is complete in the first season, farmers struggle to manage their field for the second cultivation season. They have only a short period around a month and half. These preparations normally start in mid-September until mid-January. During this time, paddy is simply rainfed (Md. Zuki \& Zulkifli 2010).

As the grain and straw ratio is $0.45: 0.55$, the estimated of rice straw which could be potentially collected in the whole MADA region is probably approximately 482,790 metric tonnes (per hectare is estimated at five metric tonnes). However, not all of the straw could probably be potentially collected, as only the top part of the plant is retrieved. Based on MADA experiences,the straw collection in low yielding fields per relung (local unit measurement of 0.288 hectares) is two bales and three bales for high yielding fields. Assuming only two bales are extracted per relung, 320 hectares of rice fields are required to produce 1000 tonnes of straw in the MADA region. this is based on an potentially estimated 301,744 tonnes of annual collection. However, based on timing and weather, the estimated actual amount in practice that could be collected in MADA region is probably half of that total of around 150,872 tonnes per year (Zulkifli, 2013).

The MADA agency provides four storage; ten units of baler machine, nine units of tractors and three units of forklifts to improve straw management (Table 1). MADA also provides incentives by free-slashing to cut stubble in the fields. This should encourage and help farmers to better manage their fields after harvesting. Based on the estimates of two straw bale per relung, the incentives given is RM20 @ RM30 per relung, and is included in operating costs.

Table 1. Facilities for straw development in the MADA region

\begin{tabular}{|lcccc|}
\hline Location & Storage (unit) & Baler machine (unit) & Tractor (unit) & Forklift (unit) \\
\hline PPK B-II, Sanglang & $200^{\prime} \times 80^{\prime}$ & 5 & 4 & 1 \\
PPK E-III, Kokbah & $120^{\prime} \times 40^{\prime}$ & 2 & 2 & 1 \\
PPK B-IV, Pengkalan Kundur & $60^{\prime} \times 40^{\prime}$ & 1 & 1 & - \\
PPK F-IV, Sungai Limau & $120^{\prime} \times 40^{\prime}$ & 2 & 2 & 1 \\
Total & 4 & 10 & 9 & 3 \\
\hline
\end{tabular}

*Note: PPK- Pertubuhan Peladang Kawasan (District Farmer's Organisation)

Source: Zulkifli, 2013.

\section{Research Methodology}

\subsection{Participants}

Farmers are being studied because they are key and the main stakeholders in ensuring the stability of rice supply and appropriate straw management in the MADA region. The population of farmers involved in the straw development project during this studies was over 267. Based on the determination of sample size (Israel, 1992), a total of 160 respondents were interviewed. It involves farmers in Region I (Perlis), Region II (Kubang Pasu), Region III (Kokbah) and Region IV (Kota Sarang Semut). Purposive sampling method is used to determine the subjects based on certain characteristics (Piaw, 2006). It involves (1) farmers who do not burn straw and allow certain parties (contractors) to collect straw on the field; and (2) farmers who use the straw for other purposes such as animal feeding and compost. A snowball sampling method is subsequently used to obtain the sample size, since MADA do not have comprehensive records of farmers involved in the straw collection project (Piaw, 2006; Babbie, 2007).

A total of 16 respondents, which is represented by four respondents in each region were interviewed in-depth to get more detailed information. The willingness of farmers to consider better straw management is very important to evaluate including their attitudes; level of motivation, knowledge and skills; ability to manage the straw in practice; strawuses especially in agriculture practices and capital capabilities.

\subsection{Instrument}

The approaches used for data collection included in-depth interviews, surveys by using questionaire and personal observations. This triangulation technique are used to support evidence and verify information obtained from various other sources (Othman, 2007). Observations were made to determine the availability of logistic facilities such as storage, 
mechanization and transportation.

\section{Findings and discussion}

\subsection{Respondents' profile}

All respondents interviewed were Malays involving 145 of men (90.6\%) and 15 of women (9.4\%). As seen on Table 2, a large number of respondents were more than 51 years old and almost in secondary education level. These prove that most of the farmers in the MADA region are elderly, and not in higher qualification level such as diploma and degree. A total of 56 respondents (35.0\%) have been working on the rice fields more than 20 years. This indicates that they have many years experince of field management.

Table 2. The respondents' profile in the MADA region

\begin{tabular}{|c|c|c|}
\hline Farmers profail & Total & Percentage (\%) \\
\hline Age & & \\
\hline Less than 20 years & - & - \\
$21-30$ years & 10 & 6.3 \\
$31-40$ years & 27 & 16.9 \\
$41-50$ years & 38 & 23.7 \\
More than 51 years & 85 & 53.1 \\
\hline Education/ qualification level & & \\
\hline Not in school & 1 & 0.6 \\
Primary school & 38 & 5.0 \\
SRP/LCE & 93 & 23.8 \\
SPM/MCE & 19 & 58.1 \\
STPM/HSC & 1 & 11.9 \\
Certificate/ Diploma & - & 0.6 \\
Degree & & - \\
\hline Duration on field working & 15 & 9.4 \\
Less than 5 years & 27 & 16.9 \\
6 - 10 years & 35 & 21.8 \\
10 - 15 years & 27 & 16.9 \\
16 - 20 years & 56 & 35.0 \\
\hline More than 20 years & & \\
\hline
\end{tabular}

*Note: SRP/ LCE: Sijil Rendah Pelajaran (Lower Certificate of Education)

SPM/ MCE: Sijil Pelajaran Malaysia (Malaysia Certificate of Education)

STPM/ HSC: Sijil Tinggi Pelajaran Malaysia (Malaysia Higher School Certificate)

\subsection{Factors influencing farmers' participation in the straw project}

Results reveal there are several factors that can influence farmers to manage their straw in more sustainable ways such as agronomy issues, facilities, institution perspectives and the farmers attitude (Table 3 ). 
Table 3. Factors influencing farmers' participation in the straw project in the MADA region

\begin{tabular}{|l|l|l|l|l|l|l|}
\hline \multirow{2}{*}{ Factors } & \multicolumn{2}{|l|}{ Yes, influenced } & \multicolumn{2}{l|}{ Less influenced } & \multicolumn{2}{l|}{ Uninfluenced } \\
\cline { 2 - 7 } & Total & $\%$ & \multicolumn{2}{l|}{ Total } & $\%$ & \multicolumn{2}{l|}{ Total } & $\%$ \\
\hline Agronomy & & & & & & \\
Conscious of weather condition & 153 & 95.6 & 5 & 3.1 & 2 & 1.3 \\
Concerned about disease and pest attack & 126 & 78.7 & 30 & 18.8 & 4 & 2.5 \\
Consider of limited time for crop management & 82 & 51.3 & 32 & 20.0 & 46 & 28.7 \\
\hline $\begin{array}{l}\text { Facilities } \\
\text { Inefficient straw collection technology }\end{array}$ & 136 & 85.0 & 24 & 15.0 & - & - \\
$\begin{array}{l}\text { Lack of logistic facilities } \\
\text { a) Baler machine }\end{array}$ & 103 & 64.4 & 57 & 35.6 & - & - \\
b) Storage & 96 & 60.0 & 60 & 37.5 & 4 & 2.5 \\
$\quad$ C) Transportation & 82 & 51.3 & 73 & 45.6 & 5 & 3.1 \\
\hline $\begin{array}{l}\text { Management by agricultural agency } \\
\text { Inefficient straw management }\end{array}$ & 12 & 7.5 & 99 & 61.9 & 49 & 30.6 \\
Unattractive incentives & 137 & 85.6 & 16 & 10.0 & 7 & 5.5 \\
\hline $\begin{array}{l}\text { Farmers' perspectives } \\
\text { Low level of skills and knowledges }\end{array}$ & 91 & 56.9 & 69 & 43.1 & - & - \\
Lack of capital & 10 & 6.3 & 52 & 32.5 & 98 & 61.2 \\
\hline
\end{tabular}

\subsubsection{Agronomy}

\section{a) Conscious of weather condition}

Crop schedule management is particularly important in determining the timeliness of planting and harvesting in the rainy season. Most farmers (95.6\%) stated that harvesting in the rainy season is a key factor to the failure of straw management in an environmentally-friendly way in the MADA region (Table 3). Due to dew and rainfall, straw in the field can become very wet. Interviews show that the wet straw could not be used as a by-product because of poor quality, and would also be mouldy when stored. This straw could only be incorporated into the soil. This situation would affect overall the supply of straw during rainy seasons, in all years.

\section{b) Concerned about disease and pest attack}

Interviews revealed that straw burning is also done to eliminate sources of pests and diseases from attacking the next crop. In fact, farmers also want to reduce the use of chemical inputs such as pesticides and herbicides that would also increase the cost of crop management and potential health problems. Moreover, according the farmers questioned (in their opinion), continuous use of chemical inputs in the field could, potentially also encourage some pest and weed problems more widely. This is stated by $78.7 \%$ of respondents that these factors also significantly influence the stagnation in straw-utilisation in the MADA region (Table 3).

\section{c) Consider of limited time for the next crop management}

Due to a short time of about a month and a half, many farmers were also forced to burn the straw immediately to clear the field for the next crop season. Delaying such straw management could have resulted in many farmers facing many difficulties for subsequent crop management. The problems would arise from timeliness of cultivations and harvesting time. This is because the water will be discharged to the field from a central-controlled irrigation system on time when farmers are no longer able to follow the schedule. This factor is stated by $51.3 \%$ respondents, while $28.7 \%$ respondents claimed that this factor is not related to the failure of developing straw-utilisation (Table 3).

\subsubsection{Facilities}

a) Inefficient straw collection technology

Farmers are very open minded on new technology. However, the technology must be appropriate to their capacity, the 
environment and farming system in their circumtances (Liew et al., 1994). Based on the results, a total of $85.0 \%$ respondents stated that the inefficient straw collection technology had led to the stagnation of straw-utilisation (Table 3).

Interviews revealed that the baler machine imported by MADA to collect straw on the field is also not suitable to local conditions, which is wet in the first season. The tyres would stick when operating in wet soil. Thus, baler machine can only be operated when harvesting is done during the second season around February and March. At that time, fields are dry due to the dry season. According to farmers, the wet straw would be mouldy, so it could only incorporated to field as a compost for enhancing soil fertility. Limited potential in wet straw was found to undermine farmers' efforts from straw development in the MADA regions.

\section{b) Lack of logistic facilities}

The MADA only has four storage, ten baler machine and nine tractors that could cover the whole of the straw collection. Around $65.5 \%$ stated that the lack of baler machine also influences farmers participation in other straw-uses, especially for fields located far away from the storage center provided by MADA (Table 3). Furthermore, the short time frame for the next crop management deters farmers spending more time waiting for the straw collection service by MADA. If the farmers wants to collect straw more individually, labour or additional workers would be required for collecting straw which is spread widely on the field and bulky. This would also increase the costs of field operations. Due to these issues, many farmers continue to burn straw just after harvesting.

Straw needs a proper storage with a roof and wide area because it is very sensitive to humidity. It will easily go mouldy when exposed to dew and rain. Around $60.0 \%$ of respondents indicates that lack of storage cause the stagnation of straw-utilisation (Table 3). Interviews also found that farmers who take the initiative to collect their own straw in the field also face difficulties for keeping the straw. This is because farmers do not have a wide area for storage building around a residential area. The straw bales are very big and heavy to handle. In fact, transportation costs are also higher if the farmer wants to send the straw at MADA's storage center. Only a few farmers stated that storage is not important, because they only have to hand over the straw management to MADA.

Interviews revealed that only a few farmers have the initiative to collect their own straw for livestock feed and composting. In fact, the study also found that a small number of farmers (10.6\%) had their own storage and normally they collected the straw itself. Most of them use the straw as animal feeding and composting. Observations revealed that although the on-farm storage is often small and simple, but it could be used to accommodate their livestock food supply. The rest of the straw that left in the field is given to certain parties to collect it or is burned in-situ.

\subsubsection{Management by agricultural agency}

\section{a) Inefficient straw management by agency}

Farmers also stated that they do not fully understand the new straw management method proposals given by extension officers. Furthermore, MADA has also encouraged farmers to collect their own straw. However, the lack of logistic facilities such as trucks provided by MADA, could sometimes result straw damage in the field due to the wet weather. Interviews revealed that farmers are also less satisfied with the agencies management. They pay less attention after a series of straw demonstration plots conducted in their fields. Farmers will be left to do its own without the constant guidance of the entension officers. This may reportedly be due to giving priority to other crops that are more profitable. This has foiled efforts of farmers to increase straw-uses, especially as a compost and straw collection during the dry season.

\section{b) Less attractive incentives}

Results record that $85.6 \%$ of farmers felt incentives given by MADA fail to encourage farmers to become more involved in new straw management (Table 3). The cost of free-slashing for stubble between RM20 and RM30 that also included operation costs is less attractive. In addition, the incentives are too low compared with their hardship from land preparation and cultivating until harvesting time. The entire operation requires full commitment of time; farmers energy; and high operating costs. For this reason, higher, and more attractive incentives could probably attract more farmers to participate in these straw development project. However, only a few respondents stated that they were not influenced by incentives to participate in straw collection project. These farmers felt the incentives given by MADA were quite sufficient. At least, through this project, the operation costs could be saved by stubble free-slashing. 


\subsubsection{Farmers perspectives}

\section{a) Farmer knowledge and low skill level}

For encouraging better straw-utilisation, farmers need to have relevant skills and knowledge from the the first step of cultivation process from choosing the variety of rice and cultivation methods, harvesting machinery, and the actual time for collecting straw (Summers et al., 2003). Results revealed that $56.9 \%$ of respondents stated that lack of skills and knowledge related to the cultivation process and straw management affected their straw-utilisation. Interviews also revealed that farmers desperately need training directly in the field especially involving the techniques of straw collecting and processing as a compost. Farmers reportedly need a two-way practical learning between extension officers and the agricultural agency, rather than just theory through seminars. According to farmers, more appropriate training methods could give them a better understanding of how straw might be better managed in more sustainable ways.

Interviews revealed that farmers need continuous advice from extension officers. They need to visit the field to identify the problems faced by farmers, and try to solve it as soon as possible. In fact, farmers seen very keen to do a demonstration plots on field. This allows the farmers to learn and practice more efficiently. In addition, farmers also need a series of visits to successfully field implemented straw projects on other farms. Analysis of interviews with several farmers who have been following the series of visits found that they get more experiences, knowledges, skills and confidence on straw-use when supported by MADA.

\section{b) Farmers' lack of capital to manage straw}

Interviews also found that inefficient management by agencies caused farmers to collect their own straw. However, the capital is very important in this effort, especially to rent a truck and baler machine and storage building. As small farmers, they don't have huge capital to handle the facilities. But, $61.2 \%$ of respondents stated that capital availability was not the problem, because they don't have initiative anyway to collect the straw. Otherwise, just let the operations to MADA and private contractors. They expect higher incentives by government for their efforts towards straw-utilisation, to progress.

\section{Conclusion}

Rice straw could potentially create a valuable added-value commodity in industry chain. However, straw development must not only be seen in terms of economic development, but also need more approaches towards more sustainable agricultural systems. Poor straw-utilisation in the MADA region is shown by straw open-burning still being widespread; imports of chemical fertilizers and animal feed remaining high; the participation of farmers in straw collection projects is still low; and the number of straw entrepreneurs still very limited. Increasing straw-utilisation on-field and off-field need to be futher promoted for agronomic and environmental reasons.

As a stakeholder, farmers should be shifting towards a more integrated approach. The government must realize that farmers are sometimes passive to reform, if it cannot be shown they will profit from their participation in a new project. Farmers also desperately need ongoing advice from the supporting agency. This is due to farmers lack of confidence and skills with regard to the introduction of new practices. This situation causes many farmers to eventually return to traditional field management through straw open-burning. Farmers know that straw burning in the field does not have a serious impact on their field and is, as well, the easier and cheaper method for managing rice fields.

Efficiently demonstration in the field; continuous advice from extension officers on theory and practice, and more encouragement from the institutions needs to be emphasized. This is because the technology of crop management, and crop pest and diseases problems are constantly changing. Therefore, farmers need to be more skilled and knowledgeable, as well as also competitive in managing their crops and crop residues.

For increasing the participation of farmers, the incentives given should be reviewed, based on the current needs in terms of field operating costs. Increasing straw potential and market expansion for the straw-uses of on-field and off-field and the whole supply chain could raise valuable by-products of rice production rather than as the source of additional production expenses. Thus, a policy that relates to open-burning of crop residues and re-use of agricultural by-products could be given more emphasis in the context of increasing productivity and profitability to farmers, towards more sustainable agricultural development.

With more full support from farmers, providing an adequate logistics; research and development at the local level including diversification potential opportunities for straw in both wet and dry condition; good crop management practices; and integrated support from agricultural agencies and government, could probably create a more competitive and progressive straw industries in the MADA region. 


\section{Acknowledgements}

Financial support by the Ministry of Education Malaysia and Universiti Kebangsaan Malaysia for post doctoral studies at the Royal Agricultural University, Cirencester, United Kingdom.

\section{References}

Allen-Stevens, T. (2014). Get more from your straw: from theory to field. Home Grown Cereals Authority (HGCA). United Kingdom. Crop Production Magazine. April 28-31.

Babbie, E. (2007). The practice of social research. United States of America: Thomson Wadsworth.

Bijay-Singh, Shan, Y.H., Johnson-Beebout, S.E., Yadvinder-Singh, \& Buresh, R.J. (2008). Crop residue management for lowland rice-based cropping systems in Asia. Advances in Agronomy, 98, 117-187.

Bird, J.A., Eagle, A.J., Horwath, W.R., Hair M.W., Zilbert, E.E., \& van Kessel, C. (2002). Long-term studies find benefits, challenges in alternative rice straw management. California Agriculture, 56 (2), 69-75.

Department of Science, Technology and Environment (2013). Policy for management and utilization of paddy straw in Punjab. Punjab: Government of Punjab.

Dobermann, A., \& Fairhurst, T. (2000). Rice: nutrient disorders and nutrient management. International Rice Research Institute (IRRI). Makati City: Philippines.

Dong, C.F., Shen, Y.X., Ding, C.L., Xu, N.X., Cheng, Y.H., \& Gu, H.R. (2013). The feeding quality of rice (Oryza sativa L.) straw at different cutting heights and the related stem morphological traits. Field Crops Research, 141, 1-8.

Erenstein, O. (2011). Cropping systems and crop residue management in the Trans-Gangetic Plains: Issues and challenges for conservation agriculture from village surveys. Agricultural Systems, 104, 54-62.

Glithero, N.J., Ramsden, S.J., \& Wilson, P. (2013). Barriers and incentives to the production of bioethanol from cereal straw: A farm business perspective. Energy Policy, 59, 161-171.

Indian Agricultural Research Institute (2012). Crop residues management with conservation agriculture: Potential, constraints and policy needs. New Delhi: Indian Agricultural Research Institute.

Israel, G.D. (1992). Determining sample size. [Online] Available: http://edis.ilfas.ufl.edu/PD006 (May 9, 2014).

Kanokkanjana, K., \& Garivait, S. (2013). Alternative rice straw management practices to reduce field open burning in Thailand. International Journal of Environmental Science and Development, 4(2), 119-123.

Kadam, K.L., Forrest, L.H., \& Jacobson, W.A. (2000). Rice straw as a lignocellulosic resource: collection, processing, transportation, and environmental aspects. Biomass and Bioenergy, 18 (5), 369-389.

Kim, S., \& Dale, B.E. (2004). Global potential bioethanol production from wasted crops and crop residues. Biomass and Bioenergy, 26, 361-375.

Liew, F.K.Y., Tulas, M.T., Awang, M.S.L., \& Mohd Dandan, A. (1993). Translating research results into practice. In. Dominic Lim (eds.). Agricultural Research Development: the need to be user sensitive. Proceedings of Seminar Kundasang, Sabah, 19-20 Ogos.

Md. Zuki, I., \& Zulkifli, R. (2010). Creating wealth from waste: the MADA experiences. In. Strengthening food security through sustainable rice production. Proceedings National Rice Conference. Swiss Garden Golf Resort and Spa Damai Laut, Lumut. 28-30 Jun.

Ministry of Economic Affairs. (2013). Rice straw and wheat straw. Potential feedstocks for the Biobased Economy. [Online] Available: http://edepot.wur.ul (July 7, 2014).

Mishra, A., Kumar, P., \& Noble, A. (2013). Assessing the potential of SRI management principles and the FFS approach in Northeast Thailand for sustainable rice intensification in the context of climate change. International Journal of Agricultural Sustainability, 11(1), 4-22.

Mohd Lokman Che Jusoh, Latifah Abd Manaf, \& Puziah Abdul Latiff. (2013). Composting rice straw with effective microorganisms (EM) and its influence on compost quality. Iranian Journal of Environmental Health Science and Engineering, 10(17), 1-9.

Othman Lebar. (2007). Penyelidikan kualitatif: pengenalan kepada teori dan metod. Tanjong Malim: Penerbit Universiti Pendidikan Sultan Idris.

Park, J., Lee, Y., Ryu, C., \& Park, Y.K. (2014). Slow pyrolysis of rice straw: analysis of products properties, carbon and energy yields. Bioresource Technology, 155, 63-70.

Piaw, C.P. (2006). Asas statistik penyelidikan. Kuala Lumpur: Mc Graw Hill.

Qian, X., Shen, G., Wang, Z., Guo, C., Liu, Y., Lei, Z., \& Zhang, Z. (2014). Co-composting of livestock manure with rice straw: Characterization and establishment of maturity evaluation system. Waste Management, 34, 530-535.

Rosmiza, M.Z., Amriah, B., \& Rosniza Aznie C.R. (2012). Impact of Rice Straw Development Towards Agricultural Environment and Farmers' Socio-Economy in MADA Region, Kedah. 2nd International Conference on History and Society Development (ICHSD). Bangkok, Thailand. International Economics Development Research Center (IEDRC). 24-25 November.

Summer, M.D., Jenkins, B.M., Hyde, P.R., Williams, J.F., Mutters, R.G., Scardacci, S.C., \& Hair M.W. (2003). Biomass production and allocation in rice with implications for straw harvesting and utilization. Biomass and Bioenergy, 24, 163-173.

Tesfaye, A., \& Chairatanayuth, P. (2007). Management and feeding systems of crop residues: the experience of East Shoa Zone, Ethiopia. Livestock Research for Rural Development, 19 (3).

Zhang, R., \& Jenkins, B.M. (2004). Commercial uses of straw. Agricultural Mechanization and Automation. Vol II. California: USA.

Zulkifli Romli (2013). Inisiatif MADA untuk meningkatkan pendapatan petani melalui pembangunan produk hiliran MADA. Persidangan Padi Kebangsaan 2013: Transformasi industri padi dan beras melalui inovasi, 10-12 Disember. Seberang Perai: Pulau Pinang. 